Reprod. Nutr. Dévelop., 1985, 25 (1 A), 1-15.

\title{
Follicular dynamics throughout the oestrous cycle in sheep. A review
}

\author{
M.-A. DRIANCOURT (1), W. R. GIBSON (*), L. P. CAHILL \\ Animal Research Institute, Werribee, Vic. 3030, Australia. \\ (*) Monash University, Clayton, Vic. 3168, Australia.
}

Summary. Whatever the stage of the cycle, follicles of various sizes are apparent on the surface of the ovary of sheep. No evidence of waves of follicular growth at fixed-time intervals has been found during the luteal phase, and growth probably occurs at random until the follicle attains a size of 4 to $7 \mathrm{~mm}$. This shows that follicles can enlarge under a wide range of hormonal levels.

The recruitment of a crop of follicles, including the one which will ovulate, occurs at variable times around luteolysis due to the interaction of endocrine and follicular factors (FSH priming, sensitizing the follicle to increased LH pulsatility). All healthy follicles $>2 \mathrm{~mm}$ in diameter are recruited. Selection of the follicle due to ovulate can be defined by morphological criteria (size) or by its « killing » ability. In all cases, the timing of follicle selection is highly variable, and it is due to this variability that the mechanisms of selection are not fully known. They are presumably intraovarian, one of the follicles actively inhibiting the growth of the others. The dominant follicle is probably maintained because of its high oestradiol content, while the others undergo atresia.

The main feature of terminal follicular development is its flexibility in terms of hormonal requirements, follicle size and the timing of the main events.

\section{Introduction.}

The ovary of adult ewes contains between 12000 and 86000 primordial follicles and between 100 and 400 growing follicles, of which 10 to 40 are visible on the surface of the ovary (Cahill, Mariana and Mauléon, 1979 ; McNatty et al., 1982). In most sheep breeds, only one follicle ovulates at the end of each oestrous cycle. The differentiation of a single preovulatory follicle is the result of a complex interaction of the ovarian follicles and the hypothalamo-pituitary axis, together with some intraovarian regulations. The aim of the present paper is to describe the main events of follicular growth in single-ovulating ewes during the oestrous cycle and the mechanisms governing these events. Observations on

(1) Present adress : Physiologie de la Reproduction, I.N.R.A. Nouzilly, 37380 Monnaie, France, to whom reprint requests should be sent. 
other species are presented when they provide additional insight into the observations on sheep; women, monkeys and mares present long follicular phases, and mares (Palmer and Driancourt, 1980) have been monitored in vitro by ultrasonic echography to study most of preovulatory follicle enlargement. For convenience, the 17-day oestrous cycle in ewes (day $0=$ oestrus) has been divided into a luteal phase lasting from days 2 to 13 and a follicular phase lasting from days 14 to 1 .

\section{Events of the luteal phase.}

Steroid and gonadotrophin leve/s. - Starting at day 3, the corpus luteum (CL) secretes increasing quantities of progesterone until day 7 , and the concentration in peripheral plasma then remains at a plateau $(1$ to $3 \mathrm{ng} / \mathrm{ml})$ until day 12 .

The pattern of $\mathrm{LH}$ concentration in the plasma during that plateau reveals that $\mathrm{LH}$ is secreted in pulses at intervals varying with the breed and the stage of the breeding season. Each pulse induces an increase in the concentrations of oestradiol and androgens in ovarian vein plasma (Baird, Swanston and Scaramuzzi, 1976). Wide fluctuations in FSH levels during this period occur from day to day within animals and between animals (L'Hermite et al., 1972 ; Salamonsen et al., 1973 ; McNeilly et al., 1976 ; Pant, Hopkinson and Fitzpatrick, 1977). The search for periodicity in these fluctuations, using autocorrelations, led to the conclusion that waves of FSH do not occur at fixed-time intervals (Miller, Nordheim and Ginther, 1981 ; Bister and Paquay, 1983). Depending on the animal, these pulses occur at short intervals of from 3.5 to 6 days, at long intervals of more than 10 days, or at both short and long intervals.

Follicular development. - It is usually assumed that, for large follicles, waves of follicular growth of 4-6 days duration occur during the luteal phase. This assumption is based on : (1) the observation of fluctuations in the size of the largest ovarian follicles of different animals on known days of the luteal phase. Brand and De Jong (1973) claimed that two waves of follicular growth could be detected during the luteal phase, one from days 1 to 10 and the other from day 6 to ovulation ; (2) studies of the fate of follicles marked by India ink at different times of the cycle and followed over a period of a few days. Smeaton and Robertson (1971) and Bherer, Matton and Dufour (1977) suggested that three waves of follicles develop during the ewe cycle : on days 6 to 9 and 13 to 15 large follicles were marked which did not ovulate, after day 15 they did; $(3$ ) the demonstration of peaks in oestradiol-17 $\beta$ secretion on days 3 and 4 (Cox, Mattner and Thorburn, 1971), 6 to 9 and 11 to 15 (Mattner and Braden, 1972).

For several reasons, however, we must proceed cautiously before concluding that waves of follicular growth exist in all animals at similar time intervals. Firstly, authors do not agree on either the number of follicular waves or on the time they occur. Secondly, the evidence for waves of follicular growth is weak since it has never been statistically documented, and the use of different animals to estimate the kinetics of follicular development is always open to criticism. Thirdly, it should be recalled that steroidogenesis is hormonally regulated and that fluctuations in 
steroid secretion might be due to fluctuations of gonadotrophin levels rather than of follicular development. In addition, there is some experimental evidence, both within and between animals, indicating a lack of follicular waves at regular intervals. An analysis of the periodicity of FSH fluctuations (Miller, Nordheim and Ginther, 1981 ; Bister and Paquay, 1983) did not demonstrate regularly occurring 4 to 6-day cycles in all animals. If follicular growth takes places in waves, FSH might be expected to fluctuate regularly and evidence low levels during the growth of a large follicle (due to oestrogen and inhibin secretions) and high levels following atresia. Also, when the blocking effect of progesterone on the $\mathrm{LH}$ peak is abolished by active immunization (French and Spennetta, 1981 ; Thomas et al., 1983), leaving the ovary in a constant, artificial, follicular phase, there is a wide variation in the intervals between ovulations (from less than $\mathbf{5}$ days to more than 15 days). Thirdly, if waves of follicular growth occur at fixed-time intervals, one might expect a higher response to PMSG and a shorter interval between prostaglandin-induced luteolysis and ovulation when the injections are given at the time a wave has developed. This has never been confirmed; the treatment of ewes with PMSG on successive days of the late luteal phase has not shown any difference between the days (Cumming and McDonald, 1967). The treatment of mares with prostaglandins at a time of the luteal phase when they present large follicles, has always resulted in a wide range of responses (Loy et al., 1979 ; Driancourt, Palmer and Bour, 1983), indicating a lack of follicular wave synchronism between animals during the luteal phase.

From the preceding considerations, it is highly possible that the growth of the large follicles during the luteal phase in sheep occurs at random. The follicles grow until they reach 4 to $6 \mathrm{~mm}$ and then regress. The number of such follicles may vary considerably among individual animals. It is not known if the changes in FSH secretion observed in some animals are linked to these random follicular changes or to intrinsic hypothalamo-pituitary activity. The high follicular activity found during the luteal phase in sheep, in which some follicles reach a size close to preovulatory size (Brand and De Jong, 1973), suggests that preovulatory enlargement can occur under a wide range of hormonal levels and pulse frequencies. This high degree of follicular activity during the luteal phase is a common feature in sheep, cows (Rajakoski, 1960) and saddle-type mares (Driancourt, Palmer and Bour, 1983), but is seldom found in women (Gougeon, 1981) or pony mares (Driancourt, Mariana and Palmer, 1982).

\section{Events of the follicular phase.}

The differentiation of the ovulating follicle is a two-step process (Di Zerega and Hodgen, 1981) in which the large antral follicles are brought forth from a pool when exposed to sufficient gonadotrophin stimulation; the development of such follicles, which are candidates for ovulation, is called " recruitment ». Next, from among these, a single follicle (in monotocous species) continues maturation, ultimately being ovulated instead of degenerating; this process is called " selection " and, as a consequence, the selected follicle becomes " dominant ". It is sometimes assumed that, at the time of recruitment, the ovulatory follicles 
are already selected because they have some characteristics which seem to indicate preselection (Tsonis et al., 1982). However, experimental elimination of a part of the recruited follicle population by unilateral ovariectomy (Findlay and Cumming, 1977), follicle cautery (Tsonis et al., 1982) or X-irradiation (Driancourt and Mariana, 1982) during the early follicular phase never results in an increase in the interval between luteolysis and ovulation in sheep. If the preselection hypothesis was valid, an extended follicular phase would have been observed in at least part of the animals due to the destruction of the follicle preselected for ovulation.

Time-lag between recruitment and attainment of preovulatory size. - Three different types of experimental models have been used to study the duration of the interval between recruitment and ovulation ; in all three, follicular growth was prevented from proceeding to ovulation by the blocking effects on gonadotrophin secretion of either a freshly ovulated follicle, a mature $\mathrm{CL}$ or seasonal anoestrus. The results obtained using these three models were : if a recently ruptured follicle was cauterized at the end of oestrus, a new follicle, able to generate another $\mathrm{LH}$ peak, was present $48 \mathrm{~h}$ later (Smeaton and Robertson, 1971) ; when a mature CL was induced to regress by a prostaglandin injection, the interval between the injection and the beginning of the $\mathrm{LH}$ surge was 48 to $55 \mathrm{~h}$ (Acritopoulou et al., $1977)$; when ovulation was induced during seasonal anoestrus by administering exogenous $\mathrm{LH}$, the time-lag between the beginning of the treatment and the $\mathrm{LH}$ peak was 30 to $50 \mathrm{~h}$ (McNatty et al., 1981a).

These results show that recruitment occurs around $48 \mathrm{~h}$ before the $\mathrm{LH}$ peak and suggest that it probably coincides with luteolysis. This is different than in rats, in which recruitment occurs at the time of the previous ovulation (Hirschfield and Midgley, 1978), and in mares in which it takes place during the late luteal phase (Driancourt, Palmer and Bour, 1983 ; Driancourt and Palmer, 1984), but it is similar to what has been described in women (Nillson, Wikland and Hamberger, 1982) and monkeys (Goodman and Hodgen, 1979a, b) (fig. 1). However, defining a mean time of recruitment might not be very meaningful since in species with a long follicular phase, the time of recruitment varies considerably; the interval from recruitment to ovulation ranges from 8 to 21 days in pony mares (Driancourt and Palmer, 1984) and from 12 to 20 days in monkeys (Goodman and Hodgen, $1979 a$, b). Recruitment is obviously a complex mechanism involving both endocrine and ovarian factors.

Mechanisms involved in recruitment. - That prostaglandin $F_{2 \alpha}$ is the luteolytic factor inducing the regression of the $\mathrm{CL}$ has been convincingly demonstrated by active (Scaramuzzi and Baird, 1976) and passive (Fairclough et al., 1975) immunization against $\mathrm{Pg} \mathrm{F}_{2 \alpha}$ which results in the persistence of the $\mathrm{CL}$. In sheep, sufficient amounts of $P G F_{2 \alpha}$ reach the ovary by day 13 via a countercurrent transfer between the utero-ovarian vein and the ovarian artery and/or via the utero-ovarian lymphatics, to cause a decline in progesterone secretion. This decline induces a marked increase in the frequency of $\mathrm{LH}$ pulses. The most convincing evidence suggesting this has been obtained by determining the consequences of premature withdrawal of progesterone, together with the 


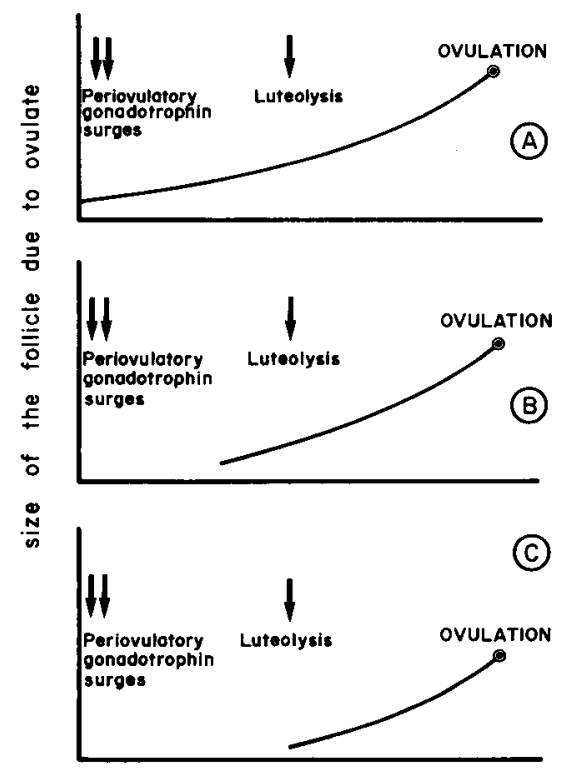

FIG. 1. - Conceptual figures depicting the different timings of recruitment. A : the onset of follicular recruitment triggered by preovulatory gonadotrophin surges (rats); B : the onset of follicular recruitment occurring during late luteal phase (mares); $\mathrm{C}$ : the onset of follicular recruitment coincident with luteolysis (sheep, monkeys, women).

insertion of blank or progesterone-filled implants (Karsch et al., 1978). After enucleation of the $\mathrm{CL}$, pulsatile $\mathrm{LH}$ secretion increases, except if the luteal phase levels of progesterone are maintained by progesterone-filled implants.

In contrast, no major change in FSH secretion has been found to coincide with luteolysis (L'Hermite et al., 1972 ; Salamonsen et al., 1973 ; McNeilly et al., 1976 ; Cahill et al., 1981).

Two questions may now be raised : how do these hormones and hormonal changes trigger recruitment? What follicles are recruited?

Insight into the hormones involved in recruitment has been provided by observations on anoestrous sheep and mares and on cyclic ewes treated with follicular fluid.

The fact that preovulatory enlargement and ovulation can be induced during anoestrus by the injection of $\mathrm{LH}$ or hCG, in amounts that produce plasma concentrations mimicking those of the follicular phase of the cycle, points to $\mathrm{LH}$ as a major hormone in recruitement (sheep : Goodman and Karsch, 1980; McNatty et al., 1981a ; mares : Driancourt, Palmer and Bour, 1983). However, several lines of evidence suggest that the follicles must be primed by FSH before they are able to respond to LH. Firstly, in lle-de-France ewes which present a deep anoestrus, as well as in pony mares in deep anoestrus in January and February, LH/hCG injections alone are unable to induce ovulation, whereas a sequence of $\mathrm{FSH}$ and $\mathrm{LH}$ injections is effective (sheep : Oussaid, Cognié and Poulin, 1982 ; mares : Driancourt, Palmer and Bour, 1983). Secondly, continuous 
administration of regular pulses of $\mathrm{LH}$ during the anoestrous season is unable to generate ovulation during the mid-anoestrous period (McNatty et al., 1984). Thirdly, the administration of prostaglandin in combination with follicular fluid (known to contain a substance that selectively decreases FSH levels) prevents the recruitment of follicles over $3 \mathrm{~mm}$ and extends the oestrous cycle by a time similar to (Miller et al., 1979) or longer than (Cummins, 1983) that of the duration of the follicular fluid treatment. However, as follicular fluid contains numerous other proteins (FSHBI : Fletcher et al., 1982 ; aromatizing inhibiting protein : Di Zerega et al., 1983 ; atresia-inducing protein : Cahill, Clarke, Driancourt and Findlay, unpublished data), the effect might not be linked to the depression of FSH levels but to a direct action of the follicular fluid proteins on the ovary. Hence, it is very likely that both FSH and LH are necessary for recruitment, the FSH priming being needed to sensitize the follicles to $\mathrm{LH}$. The magnitude of the FSH changes required for this priming is still unknown.

Estimates of the lower size limit of the recruited follicles have been obtained by four observations : (1) the study of the kinetics of individual follicle growth followed in vivo by ink labelling showed that the follicle which ovulated was recruited from those of any size $>2 \mathrm{~mm}$ at the time of natural (Driancourt, Cahill and Bindon, 1985) or induced (Driancourt and Cahill, 1984) luteolysis (fig. 2) ; (2) the destruction of follicles of different size classes by cautery did not significantly delay ovulation, if some follicles $>2 \mathrm{~mm}$ (either 2 to $4 \mathrm{~mm}$ or $>4 \mathrm{~mm}$ ) were left untouched but ovulation was delayed when all the follicles $>2 \mathrm{~mm}$ were cauterized; (3) the number of follicles $>2 \mathrm{~mm}$ was unchanged in cycles induced by prostaglandin injection alone (McNatty et al., 1982) or in conjunction with PMSG (Dott et al., 1979) ; (4) while the induction of ovulation in seasonal anoestrus by exogenous LH resulted in ovulation with a time-lag similar to that occurring after luteolysis during cyclic activity, the size of the largest follicles in anoestrous ovaries was around $3 \mathrm{~mm}$ (Smeaton and Robertson, 1971; McNatty et al., 1981a). This strongly suggests that only follicles $>2 \mathrm{~mm}$ in diameter are able to be recruited. That follicles $<2 \mathrm{~mm}$ are

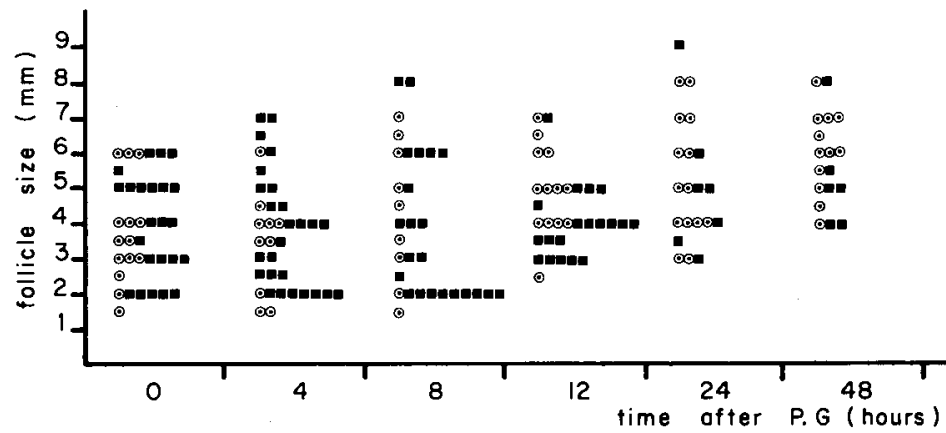

FIG. 2. - Changes in the number and size of ovulatory follicles ( $\odot)$ and of non-ovulatory follicles of a size within the range of the ovulatory ones (a) during a prostaglandin-induced follicular phase. At a given time after prostaglandin a follicle is said to be ovulatory when found to have ovulated at the second laparotomy performed $48 \mathrm{~h}$ after oestrus (reproduced by courtesy of $\mathrm{J}$. Reprod. Fert.). 
little sensitive to recruitment agrees well with the observation that follicular growth progresses to $2 \mathrm{~mm}$ in hypophysectomized ewes (Dufour, Cahill and Mauléon, 1980).

An examination of the growth kinetics of individual follicles throughout the follicular phase, using repeated laparotomy and ink labelling, suggests that all healthy follicles $>2 \mathrm{~mm}$ are recruited (Driancourt and Cahill, 1984). The number of such recruitable follicles seems to depend on the FSH levels in the $24 \mathrm{~h}$ preceding luteolysis since ewes infused with FSH from $24 \mathrm{~h}$ before until $60 \mathrm{~h}$ after induced luteolysis had a mean ovulation rate of 8 compared with an ovulation rate of 3 for ewes in which infusion was started at luteolysis (Baird and Webb, personal communication).

Appearance of a dominant follicle and atresia of the others. - As the follicular phase progresses and the increasingly frequent $\mathrm{LH}$ pulses lead to the recruitment of follicles $>2 \mathrm{~mm}$, these follicles begin to secrete more oestrogen. Despite the smaller amplitude of LH pulses (linked to oestrogen feedback: Goodman et al., 1981), more oestradiol is secreted in response to each pulse than at the earlier stages of the cycle (Baird, 1978). The repeated LH pulses induce bursts of oestrogen secretion, and these summate to produce a rise in plasma oestrogen concentration. These increased oestrogen levels have two effects : they induce oestrous behaviour and they reduce FSH secretion since oestrogens are a component of the negative feedback on FSH in sheep (Goodman, Pickover and Karsch, 1981).

One of two sets of criteria is generally used to determine that the selection of the ovulatory follicle has occurred : (1) the presence of a big follicle (monkeys : Clark et al., 1979) secreting enough oestradiol to induce an asymmetry in the concentrations of this steroid in ovarian blood (monkeys : Di Zerega et al., 1980 ; sheep : McNatty et al., 1982) and binding LH on both the theca and granulosa layers (monkeys : Di Zerega and Hodgen, 1980a; sheep : Webb and England, 1982), or (2) the presence of a " killer " follicle which causes the other follicles to degenerate, as shown by their decreasing size when followed by daily echography (mares: Driancourt and Palmer, unpublished data), by the long time-interval between ablation and ovulation (monkeys: Goodman and Hodgen, 1979a ; mares : Driancourt and Palmer, 1984), or by the lack of a stimulatory effect of exogenous gonadotrophins (monkeys: Di Zerega and Hodgen, 1980b ; mares : Woods and Ginther, 1983). While in monkeys, the definition of selection by either of the critera gives similar results, this is not true for mares since killing ability appears often after selection according to size (fig. 3 ).

The data in sheep are not clear due to the shorter duration of the events of the follicular phase. According to McNatty et al. (1982), a dominant follicle (as evidenced by asymmetrical ovarian secretion of oestradiol) is detectable as early as $10 \mathrm{~h}$ after prostaglandin injection. This claim of early selection is difficult to reconcile with the finding that unilateral ovariectomy performed before day 16 of the cycle does not affect the ovulation rate (Findlay and Cumming, 1977), suggesting that selection occurs only late in the follicular phase. In fact, defining a mean selection time is probably meaningless since, whatever the criterion used, a main feature of selection is that the time of its occurrence varies greatly, as 


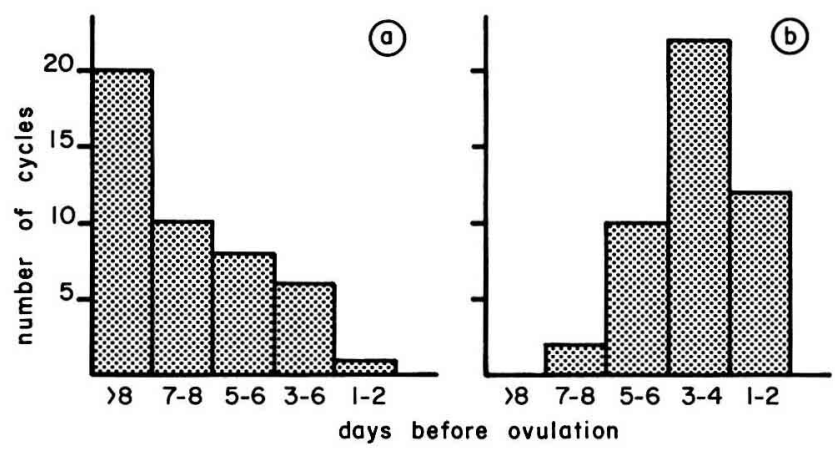

FIG. 3. - Time of the appearance of a dominant follicle (" selection ") in the mare using (a) size as a criterion; (b) follicle killing ability as a criterion.

shown for mares on figure 3 . This has also been demonstrated in sheep after ink labelling of individual follicles. At $0,4,8,12,24$ and $48 \mathrm{~h}$ after a prostaglandin injection, the follicle ovulating at the following oestrus was the largest in $0 / 7,1 / 7$, $1 / 7,4 / 7,5 / 7$ and $5 / 7$ ewes, respectively (Driancourt and Cahill, 1984). A similar conclusion can be drawn from studies in monkeys (Clark et al., 1979 ; Di Zerega et al., 1980). This variability makes it difficult to analyse mechanisms of selection since, at a given time, selection may have occurred in some animals and not in others, resulting in a mixture of the causes and consequences of selection.

The mechanisms by which a single follicle is selected while the others undergo atresia are still unclear. In most cases $(70 \%)$, it is the largest healthy follicle (i.e. growing when followed by ink labelling between days 13 and 15 of the cycle) at the time of luteolysis which is selected (Driancourt, unpublished data). However, the fact that this is not a general rule makes it necessary to postulate that some follicles, even though large and healthy, may not be as competent as others to complete preovulatory enlargement due to their improper morphological (number and/or quality of granulosa cells) of functional (ability of granulosa cells to divide or to differentiate gonadotrophin receptors) features.

The selection of a dominant follicle and the atresia of the others is usually assumed to be due to decreasing FSH levels at that time. While the role of FSH in atresia is well documented (Welschen and Dullaart, 1976), the factors protecting one follicle from death are very unclear, since all the follicles are bathed by similar concentrations. Two different hypotheses could explain this selection. The first one, which could be called the hypothesis of " developmental stability ", suggests that when a follicle is big enough or has reached a given stage of maturation, it manages to stay in a state of equilibrium. When it is in this state, due to its morphological and functional features it does not respond to the decreasing FSH levels which urge the other follicles on to atresia. Although there is no evidence ruling out this hypothesis, numerous data show that the second hypothesis, that of "active elimination ", is more likely. According to this hypothesis, selection would be an active process by which one follicle at a given size and stage of maturation actively inhibits the growth of other follicles. Results supporting this thesis have been obtained after gonadotrophin administration in 
the presence or absence of a dominant follicle (monkeys : Di Zerega and Hodgen, 1980b; women: Gougeon, Lefèvre and Testart, 1983). Furthermore, some compounds possibly involved in this action have been detected in human follicular fluid from the dominant follicle (Di Zerega et al., 1983), in the ovarian venous blood draining that type of follicle (Di Zerega, Goebelsmann and Nakamura, 1982) and in ovine follicular fluid (Cahill, Clarke, Driancourt and Findlay, unpublished data). Finally, active immunization against partially purified follicular fluid leads to an increased ovulation rate, despite unaffected FSH levels, suggesting that the antibodies raised by immunization are not against inhibin but rather against the selection-inducing compound (O'Shea et al., 1983).

Whatever the mechanism of selection, it is bypassed when PMSG is injected.

As a result of selection, all the recruited follicles except one become atretic. The factors implicated in further atresia have been described. The aromatizing activity of early atretic follicles might be reduced either by a local mediator or by greater follicle susceptibility to declining concentrations of FSH. The increasing $\mathrm{LH}$ levels stimulate the production of androgens which are no longer converted to oestrogens. Their accumulation and conversion to $5 \alpha$-dihydrotestosterone leads to a decrease in mitotic index (Hillier and Ross, 1979), a further decrease in aromatase activity (Hillier et al., 1980), and a lowered sensitivity to gonadotrophins (Farookhi, 1980), thus driving the follicle further towards atresia. Together with this shift in steroid synthesis in sheep, the size of the atretic follicles is reduced by $1.6 \mathrm{~mm}$ per day, a rate unaffected by the progression of atresia (Driancourt and Cahill, 1984).

Maintenance of the dominant follicle. - Once a dominant follicle appears, its growth rate begins to decrease while atresia progresses in the unselected follicles and recruitment is blocked (Driancourt and Cahill, 1984). A further increase in its oestradiol secretion results in a peak of oestradiol concentration around 40 to $50 \mathrm{~h}$ after an injection of prostaglandins (Baird, Swanston and McNeilly, 1981). FSH levels decrease due to the increasing feedback of both oestrogens and inhibin and, in spite of this, the dominant follicle remains healthy.

Maintenance of the dominant follicle can only be explained by the " developmental stability " hypothesis. Three factors have been claimed to contribute to this developmental stability : high intrafollicular FSH levels, high blood flow, and the high oestradiol content of the dominant follicle. Neither of the first two factors seems very plausible. Although it has been shown that a pool of healthy large follicles has a higher follicular fluid content of $\mathrm{FSH}$ than a pool of atretic ones (McNatty et al., 1981b), it has not been demonstrated that the dominant follicle has a particularly high $\mathrm{FSH}$ level. Furthermore, the $\mathrm{FSH}$ concentrations in preovulatory bovine follicles have been shown to be highly variable (Dieleman et al., 1983). The data suggesting a role of blood flow in the maintenance of the dominant follicle are also confusing. Firstly, the ligation of one ovary, chronically reducing its blood supply, does not completely block ovulation in that ovary (rats : Peppler, 1975 ; monkeys : Wehrenberg et al., 1979). Secondly, measurement of the blood flow to individual follicles by the microsphere technique has shown no difference between large follicles at the beginning of oestrus (no dominant follicle) and those at late oestrus (Bruce and Moor, 1976). 
However, morphological studies of the dominant follicle in monkeys have demonstrated a higher density of blood vessels in its theca layer than in the other follicles (Zeleznik, Schuler and Reichert, 1981).

In contrast, a role of intrafollicular oestradiol in maintaining the dominant follicle can be postulated from observations showing that oestrogens sensitize ovarian granulosa cells to gonadotrophins (Payne and Runser, 1958 ; Richards, 1975), possibly by triggering the differentiation of gonadotrophin receptors (Richards, 1979).

What is striking, however, is that the developmental stability attained is very fragile. Any decrease in the FSH levels produced by injecting oestrogens (Clark, Dierschke and Wolf, 1981 ; Zeleznik, 1981) or anti-PMSG (Bindon and Piper, 1982 ) induces atresia of the dominant follicle in monkeys or reduces the ovulation rate in superovulated ewes.

From the $L H$ peak to ovulation. - In sheep, as in most species studied, there is strong evidence that the preovulatory surges of $\mathrm{LH}$ and $\mathrm{FSH}$ that occur 50 to $60 \mathrm{~h}$ after a prostaglandin injection (Chamley et al., 1972 ; Baird, Swanston and McNeilly, 1981) are provoked by a rise in oestrogen secretion in the preovulatory follicle. In cyclic ewes, increases in oestrogen secretion always precede preovulatory LH surge (Chamley et al., 1972). Passive immunization of ewes against oestradiol prevents the LH surge (Scaramuzzi, 1975). Oestradiol administration to properly primed ovariectomized ewes provokes an LH surge (Pant, 1977). The mechanisms triggering the $\mathrm{LH}$ peak are well documented. Both an increased frequency of $\mathrm{GnRH}$ discharges and an increased sensitivity of the pituitary gland to $\mathrm{GnRH}$, induced by high oestradiol levels (Reeves, Arimura and Schally, 1971), result in a rapid elevation of the $\mathrm{LH}$ levels as soon as the frequency of $\mathrm{GnRH}$ discharges is high enough in relation to the half-life of $\mathrm{LH}$ to permit summation to occur. Peaks of FSH and prolactin occur with the $\mathrm{LH}$ peak.

The preovulatory surge of $\mathrm{LH}$ initiates a sequence of changes in the steroidogenesis of the dominant follicle and in its structure, as it prepares to expel the oocyte.

At the time of ovulation, the plasma FSH concentration shows a rise that is longer than the preovulatory elevation but which reaches the same peak levels. There is no coincident rise in LH concentration or pulse frequency. The factors causing the second FSH peak are not fully known; it cannot be blocked by the administration of pentobarbitone or antiserum to LH-RH (Dobson and Ward, 1977 ; Narayana and Dobson, 1979) or by the maintenance of high oestradiol levels (Chappel and Barraclough, 1977), but is abolished by inhibin (Marder, Channing and Schwartz, 1977; Schwartz and Channing, 1977) and passive immunization against testosterone (Gay and Tomacari, 1974). While the role of this second FSH peak has been demonstrated in the recruitment of a group of follicles due to ovulate at the next cycle in rats (Chappel and Selker, 1979), its function, if any, is unknown in sheep. Early claims that this peak triggers the development of the follicles ovulating at the next cycle (Cahill et al., 1981) have not been confirmed by further studies in which the peak was blocked by follicular fluid, without any changes in the next ovulation (Cummins, 1983). 


\section{Conclusion.}

What emerges from the present data is the flexibility of terminal follicular growth. This is apparent (1) in the hormonal needs for preovulatory growth which are similarly evidenced during the follicular and the luteal phases (2) in the size at recruitment of the follicle which finally ovulates and (3) in the timing of the main events of preovulatory follicle differentiation. A similar flexibility in the way prolific sheep breeds generate a high ovulation rate has also been demonstrated in Booroola ewes which show different mechanisms than Romanov ewes (Driancourt et al., 1985 ; Driancourt, unpublished data). Any studies dealing with the control of the mechanisms of preovulatory follicle enlargement will have to take this flexibility into consideration.

Reçu en février 1984.

Accepté en juillet 1984.

\section{Résumé. Croissance folliculaire terminale au cours du cycle chez la Brebis.}

Chez la brebis, pendant tout le cycle, il existe des follicules visibles sur l'ovaire. Pendant la phase lutéale, il n'existe pas de vagues de croissance folliculaire à intervalles réguliers mais plutôt une croissance au hasard de follicules qui atteignent 4 à $7 \mathrm{~mm}$. Ceci démontre que des follicules de taille presque préovulatoire peuvent se développer en présence de niveaux hormonaux très différents de ceux de la phase folliculaire.

Le recrutement d'un groupe de follicules parmi lequel se trouve celui qui ovulera se produit à un moment variable mais centré sur la lutéolyse. II résulte de l'interaction des niveaux hormonaux et des caractéristiques des follicules (imprégnation des follicules par FSH qui les sensibilise à l'augmentation de la fréquence des pulses de LH). Tous les follicules sains excédant $2 \mathrm{~mm}$ de diamètre sont recrutés. Le moment de la sélection du follicule qui ovulera peut être défini par des critères morphologiques (taille) ou par son aptitude à induire la régression des autres follicules. Quel que soit le critère, le moment de la sélection est très variable. Le mécanisme de sélection est probablement intraovarien, un des follicules inhibant la croissance des autres. Le maintien du follicule dominant alors que les autres régressent est probablement lié aux concentrations élevées en oestradiol qu'il contient.

La caractéristique principale du développement préovulatoire est sa flexibilité : 1) vis-àvis de ses besoins en hormones 2) quant à la taille des follicules impliqués 3) quant aux moments où se produisent ses différentes étapes.

\section{References}

ACRITOPOULOU S., HARESIGN W., FOSTER J. P., LAMMING G. E., 1977. Plasma progesterone and $\mathrm{LH}$ concentrations in ewes after injection of an analogue of prostaglandin $\mathrm{F}_{2 \alpha}$. J. Reprod. Fert., 49, 337-340.

BAIRD D. T., 1978. Pulsatile secretion of LH and ovarian estradiol during the follicular phase of the sheep estrous cycle. Biol. Reprod., 18, 359-364.

BAIRD D. T., SWANSTON I. A., MCNEILLY A. S., 1981. Relationship between LH, FSH and prolactin concentration and the secretion of androgens and estrogens by the preovulatory follicle in the ewe. Biol. Reprod., 24, 1013-1025.

BAIRD D. T., SWANSTON I. A., SCARAMUZZI R. J., 1976. Pulsatile release of LH and secretion of ovarian steroids in sheep during the phase of the estrous cycle. Endocrinologr, 98, 1490-1496. 
BHERER J., MATTON P., DUFOUR J. J., 1977. Fate of the two largest follicles in the ewe after injection of gonadotropins at two stages of the estrous cycle. Proc. Soc. exp. Biol. Med., 154. 412-414.

BINDON B. M., PIPER L. R., 1982. Physiological basis of the ovarian response to PMSG in sheep and cattle. In Egg transfer in cattle, sheep and goat, Austr. Soc. Reprod. Biol. ed., Camberra.

BISTER J. L., PAQUAY R., 1983. Fluctuations in the plasma levels of the follicle-stimulating hormone during estrous cycle, anestrus, gestation and lactation in the ewe : evidence for an endogenous rhythm of FSH release. Theriogenology, 19, 565-581.

BRAND A., De JONG W. H. R., 1973. Qualitative and quantitative micromorphological investigations of the tertiary follicle population during the oestrous cycle in sheep. J. Reprod. Fert., 33, 431-439.

BRUCE N. W., MOOR R. M., 1976. Capillary blood flow to ovarian follicles, stroma and corpora lutea of anesthetized sheep. J. Reprod. Fert., 46, 229-304.

CAHILL L. P., MARIANA J. C., MAULEON P., 1979. Total ovarian follicular populations in ewes of high and low ovulation rate. J. Reprod. Fert., 55, 27-36.

CAHILL L. P., SAUMANDE J., RAVAULT J. P., BLANC M., THIMONIER J., MARIANA J. C., MAULÉON P., 1981. Hormonal and follicular relationships in ewes of high and low ovulation rate. J. Reprod. Fert., 62, 141-150.

CHAMLEY W. A., BUCKMASTER J. M., CAIN M. D., CERINI J., CERINI M. E., CUMMING I. A., GODING J. R., 1972. The effect of prostaglandin $F_{2 \alpha}$ on progesterone, estradiol and luteinizing hormone secretion in sheep with ovarian transplants. J. Endocr., 55, 253-263.

CHAPPEL S. C., BARRACLOUGH C. A., 1977. Further studies on the regulation of FSH secretion. Endocrinology, 101, 24-31.

CHAPPEL S. C., SELKER F., 1979. Relation between the secretion of FSH during the periovulatory period and ovulation during the next cycle. Biol. Reprod., 21, 347-352.

CLARK J. R., DIERSCHKE D. J., WOLF R. C., 1979. Hormonal regulation of ovarian folliculogenesis in rhesus monkeys. Serum concentrations of estradiol-17 $\beta$ and follicle-stimulating hormone associated with growth and identification of the preovulatory follicle. Biol. Reprod., 21, 497503.

COX R. I., MATTNER P. E., THORBURN G. D., 1971. Changes in ovarian secretion of estradiol-17 $\beta$ around estrus in the sheep. J. Endocr., 49, 345-346.

CUMMING I. A., McDONALD M. F., 1967. The production of ova by N. Z. Romney ewes following hormonal stimulation. N. Z. J. agr. Res., 10, 226-236.

CUMMINS L., 1983. Physiological basis of the control of ovulation rate in sheep. Ph. D. Th. Univ. New-England, Armidale, Australia.

DIELEMAN S. J., BEVERS M. M., POORTMAN J., VAN TOL H. T. M., 1983. Steroid and pituitary hormone concentrations in the fluid of preovulatory bovine follicles relative to the peak of LH in the peripheral blood. J. Reprod. Fert., 69, 641-649.

Di ZEREGA G. S., GOEBELSMANN U., NAKAMURA R., 1982. Identification of protein(s) secreted by the preovulatory ovary which suppress follicular response to gonadotropins. $J$. clin. Endocr. Metab., 54, 1091-1096.

Di ZEREGA G. S., HODGEN G. D., 1980a. Fluorescence localisation of luteinizing hormone/human chorionic gonadotropin uptake in the primate ovary. Changing distribution during selection of the dominant follicle. J. clin. Endocr. Metab., 51, 903-907.

Di ZEREGA G. S., HODGEN G. C., 1980b. The primate ovarian cycle: suppression of human menopausal gonadotropin induced follicular growth in the presence of the dominant follicle. J. clin. Endocr. Metab., 50, 819-825.

Di ZEREGA G. S., HODGEN G. D., 1981. Folliculogenesis in the primate ovarian cycle. Endocr. Rev., 2, 27-49.

Di ZEREgA G. S., MARRS R. P., ROCHE P. C., CAMPEAU J. D., KLING O. R., 1983. Identification of proteins in pooled human follicular fluid which suppress follicular response to gonadotropins. J. clin. Endocr. Metab., 56, 35-41.

Di ZEREGA G. S., MARUT E. L., TURNER C. K., HODGEN G. D., 1980. Asymmetrical ovarian function during recruitment and selection of the dominant follicle in the menstrual cycle of the rhesus monkey. J. clin. Endocr. Metab., 51, 698-701. 
DOBSON H., WARD W. R., 1977. Alterations in plasma gonadotrophin patterns caused by sodium pentobarbitone in ewes at oestrus and in anoestrus ewes after infusion of oestradiol. $J$. Endocr., 75, 109-118.

DOTT H. M., HAY M. F., CRAN D. G., MOOR R. M., 1979. Effects of exogenous gonadotrophin (PMSG) on the antral follicle population in the sheep. J. Reprod. Fert., 56, 683-689.

DRIANCOURT M. A., CAHILL L. P., 1984. Preovulatory follicular events in sheep. J. Reprod. Fert., 71. 205-211.

DRIANCOURT M. A., CAHILL L. P., BINDON B. M., 1985. Preovulatory enlargement in strains of Merino with high and low prolificacy. J. Reprod. Fert., 73 (in press).

DRIANCOURT M. A., MARIANA J. C., 1982. Short and long-term effects of X-irradiation on ovarian follicular populations in the ewe. Reprod. Nutr. Dévelop., 22, 813-823.

DRIANCOURT M. A., MARIANA J. C., PALMER E., 1982. Effect of the stage of the oestrous cycle on the follicular population in pony mares. Reprod. Nutr. Dévelop., 22, 803-812.

DRIANCOURT M. A., PALMER E., 1984. Time of ovarian follicular recruitement in cycling pony mares. Theriogenology, 21, 591-600.

DRIANCOURT M. A., PALMER E., BOUR B., 1983. Croissance préovulatoire chez la jument, 101-114. In THIBAULT C., SALAT BAROUX J., La période péri-ovulatoire, Masson, Paris.

DUFOUR J. J., CAHILL L. P., MAULÉON P., 1980. Short and long-term effects of hypophysectomy and unilateral ovariectomy on ovarian follicular populations in sheep. J. Reprod. Fert., 57, 301-309.

FAIRCLOUGH R. J., SMITH J. F., PETERSON A. J., McGOWAN L., 1975. Effect of oestradiol-17 $\beta$, progesterone and $\mathrm{Pg} \mathrm{F}_{2 \alpha}$-antiplasma on luteal function in the ewe. J. Reprod. Fert., 46, 523524.

FAROOKHI R., 1980. Effects of androgen on induction of gonadotropin receptors and gonadotropin stimulated AMP production in rat ovarian granulosa cells. Endocrinology, 106, 1216-1223.

FINDLAY J. K., CUMMING I. A., 1977. The effect of unilateral ovariectomy on plasma gonadotropin levels, estrus and ovulation rate in the sheep. Biol. Reprod., 17, 178-183.

FLETCHER P. W., DIAS J. A., SANZO M. A., REICHERT L. E., 1982. Inhibition of FSH action on granulosa cells by low molecular weight components of follicular fluid. Mol. cell. Endocr., 25, 303-315.

FRENCH L. R., SPENNETTA B., 1981. Effect of antibodies to progesterone on reproduction in ewes. Theriogenology, 16, 407-418.

GAY V. L., TOMACARI R. L., 1974. Follicle-stimulating hormone secretion in the female rat : cyclic release in dependant on circulating androgen. Science, 184, 75-77.

GOODMAN A. L., HODGEN G. D., 1979a. Between ovary interaction in the regulation of follicular growth, $\mathrm{CL}$ function and gonadotropin secretion in the primate ovarian cycle: I. Follicle cautery and hemicastration in follicular phase. Endocrinology, 104, 1304-1309.

GOODMAN A. L., HODGEN G. D., 1979b. Between ovary interaction in the regulation of follicular growth, CL function and gonadotropin secretion in the primate ovarian cycle : II. Luteectomy and hemi-castration during the luteal phase. Endocrinology, 104, 1310-1316.

GOODMAN R. L., BITTMAN E. L., FOSTER D. G., KARSCH F. J., 1981. The endocrine basis of the synergistic suppression of luteinizing hormone by estradiol and progesterone. Endocrinology, $109,1414-1417$.

GOODMAN R. L., KARSCH F. J. 1980. Control of seasonal breeding in the ewe : importance of changes in response to sex steroid feedback. Progr. Reprod. Biol., 5, 134-154.

GOODMAN R. L., PICKOVER S. M., KARSCH F. J., 1981. Ovarian feedback control of follicle-stimulating hormone in the ewe : evidence for selective suppression. Endocrinology, 108, $772-777$.

GOUGEON A., 1981. Cinétique de la croissance et de l'involution des follicules ovariens pendant le cycle menstruel chez la femme. Th. Doct. Etat Sci. nat., Paris VI.

GOUGEON A., LEFEVRE B., TESTART J., 1983. Recrutement et sélection du follicule dominant pendant le cycle menstruel spontané ou stimulé chez la femme, 1-11. In C. THIBAULT, J. SALAT BAROUX. La période péri-ovulatoire. Masson, Paris.

HILLIER S. G., ROSS G. T., 1979. Etfects of exogenous testosterone on ovarian weight, follicular morphology, and intraovarian progesterone concentration in estrogen-primed hypophysectomized immature female rats. Biol. Reprod., 20, 261-268. 
HILLIER S. G., VAN DEN BOOGAARD A. M. J., REICHERT L. E., VAN HALL E. V., 1980. Alterations in granulosa cell aromatase activity accompanying preovulatory follicular development in the rat ovary with evidence that $5 \alpha$ reduced C19 steroids inhibit the aromatase reaction in vitro. J. Endocr., 84, 409-419.

HIRSCHFIELD A. N., MIDGLEY A. R., 1978. Morphometric analysis of follicular development in the rat. Biol. Reprod., 19, 597-605.

KARSCH F. J., LEGAN S. J., RYAN K. D., FOSTER D. L., 1978. The feed-back effects of ovarian steroïds on gonadotrophin secretion, 29-49. In CRIGHTON D. B., HAYNES N. B., FOXCROFT G. R., LAMMING G. E., Control of ovulation. Butterworths, London.

L'HERMITE M., NISWENDER G. D., REICHERT L. E., MIDGLEY A. R., 1972. Serum folliclestimulating hormone in sheep as measured by radioimmunoassay. Biol. Reprod., 6, 325-332.

LOY R. G., BUELL J. R., STEVENSON W., HAMM D., 1979. Sources of variation in response intervals after prostaglandin treatment in mares with functional corpora lutea. J. Reprod. Fert., Suppl. 27, 229-235.

MCNATTY K. P., GIBB M., DOBSON C., BALL K., COSTER J., HEATH D., THURLEY D. C., 1982. Preovulatory follicular development in sheep treated with PMSG and/or prostaglandin. $J$. Reprod. Fert., 65, 111-123.

MCNATTY K. P., GIBB M., DOBSON C., THURLEY D. C., 1981a. Evidence that changes in luteinizing hormone secretion regulate the growth of the preovulatory follicle in the ewe. J. Endocr., 90, 375-389.

MCNATTY K. P., GIBB M., DOBSON C., THURLEY D. C., FINDLAY J.K. 1981b. Changes in the concentrations of gonadotrophic and steroïdal hormones in the antral fluid of ovarian follicles throughout the oestrous cycle of the sheep. Aust. J. biol. Sci., 34, 67-80.

MCNATTY K. P., HUDSON N., GIBB M., BALL K., Fannin J., KIEBOOM L., THURLEY D. C., 1984. Effects of long-term treatment with $\mathrm{LH}$ on induction of cyclic ovarian activity in seasonally anoestrous ewes. J. Endocr., 100, 67-73.

MCNEILLY J. R., MCNEILLY A.S., WALTON J.S., CUNNINGHAM F.J., 1976. Development and application of a heterologous radioimmunoassay for ovine follicle-stimulating hormone. $J$. Endocr., 70, 69-79.

MARDER M. L., CHANNING C. P., SCHWARTZ N. B., 1977. Suppression of serum folliclestimulating hormone in intact and acutely ovariectomized rats by porcine follicular fluid. Endocrinology, 101, 1639-1642.

MATTNER P. E., BRADEN A. W. H., 1972. Secretion of oestradiol-17 $\beta$ by the ovine ovary during the luteal phase of the oestrous cycie in relation to ovulation. J. Reprod. Fert., 28, 136-137.

MILLER K. F., CRITSER J. K., GINTHER O. J., 1982. Inhibition and subsequent rebound of FSH secretion following treatment with bovine follicular fluid in the ewe. Theriogenology, 18, 4553.

MILLER K. F., CRISTER J. K., ROWE R. F., GINTHER O. J., 1979. Ovarian effects of bovine follicular fluid treatment in sheep and cattle. Biol. Reprod., 21, 537-544.

MILLER K. F., NORDHEIM E. V., GINTHER O. J., 1981. Periodic fluctuations in FSH concentrations during the ovine estrous cycle. Theriogenology, 16, 669-679.

NARAYANA K., DOBSON H., 1979. Effect of administration of antibody against GnRH on the preovulatory LH and FSH surges in the sheep. $J$. Reprod. Fert., 57, 65-72.

NILLSON L., WIKLAND M., HAMBERGER L., 1982. Recruitment of an ovulatory follicle in the human following follicle ectomy and lutectomy. Fert. Steril, 37, 30-34.

O'SHEA T., AL-OBAIDI S. A. R., BINDON B. M., HILLARD M. A., FINDLAY J. K., 1983. Ovarian activity in ewes vaccinated with an inhibin-enriched fraction from bovine follicular fluid. Proc. aust. Soc. Reprod. Biol., 15, 22 (Abst.).

OUSSAÏD B., COGNIÉ Y., POULIN N., 1982. Induction of ovulation by pulsed injections of LH and LH + FSH in seasonally anoestrus ewes. Proc. S.S.F., Nottingham.

PALMER E., DRIANCOURT M. A., 1980. Use of ultrasonic echography in equine gynecology. Theriogenology, 13, 203-216.

PANT H. C., 1977. Effect of androgens on concentration of LH and FSH in the peripheral plasma of anoestrous ewes. J. Reprod. Fert., 50, 133-136.

PANT H. C., HOPKINSON C. R. N., FITZPATRICK R. J., 1977. Concentration of oestradiol, 
progesterone, luteinizing hormone and follicle-stimulating hormone in the jugular venous plasma of ewes during the oestrous cycle. J. Endocr., 73, 247-255.

PAYNE R. W., RUNSER R. H., 1958. The influence of estrogen and androgen on the ovarian response of hypophysectomised immature rats to gonadotropins. Endocrinology, 62, 313-320.

PEPPLER R. D., 1975. Effect of uterine ligation on ovulation in the rat. Anat. Rec., 184, 183-186.

RAJAKOSKI E., 1960. The ovarian follicular system in sexually mature heifers with special reference to seasonal, cyclical and left-right variations. Acta. endocr., Suppl. 52, 7-68.

REEVES J. J., ARIMURA A., SCHALLY A. V., 1971. Pituitary responsiveness to purified luteinizing hormone-releasing hormone ( $\mathrm{LH}-\mathrm{RH})$ at various stages of the estrous cycle in sheep. J. anim. Sci., 32, 123-126.

RICHARDS J. S., 1975. Estradiol receptor content in rat granulosa cells during follicular development : modification by estradiol and gonadotropins. Endocrinology, 97, 1174-1182.

RICHARDS J. S., 1979. Hormonal control of ovarian follicular development : a 1978 perspective. Recent Progr. Horm. Res., 35, 343-397.

SALAMONSEN L. A., JONAS H. A., BURGER H. G., BUCKMASTER J. M., CHAMLEY W. A., CUMMING I. A., FINDLAY J. K., GODING J. R., 1973. A heterologous radioimmunoassay for follicle-stimulating hormone : application to measurement of $\mathrm{FSH}$ in the ovine estrous cycle and in several other species including man. Endocrinology, 93, 610-618.

SCARAMUZZI R. J., 1975. Inhibition of oestrous bahaviour in ewes by passive immunization against oestradiol-17ß. J. Reprod. Fert., 42, 145-148.

SCARAMUZZI R. J., BAIRD D. T., 1976. The oestrous cycle of the ewe after active immunization against prostaglandin $\mathrm{F}_{2 \alpha}$. J. Reprod. Fert., 46, 39-47.

SCHWARTZ N. B., CHANNING C. P., 1977. Evidence of ovarian " inhibin »: suppression of the secondary rise in serum follicle-stimulating hormone levels in proestrous rats by injection of porcine follicular fluid. Proc. nat. Acad. Sci. U.S.A., 74, 5721-5724.

SMEATON T. C., ROBERTSON H. A., 1971. Studies on the growth and atresia of graafian follicles in the ovary of the sheep. J. Reprod. Fert., 25, 243-252.

THOMAS G. B., HOSKINSON R. M., SCARAMUZZI R. J., OLDHAM C. M., 1983. Active immunization of merino ewes against progesterone : a study of oestrus, ovulation and secretion of LH. Proc. aust. Soc. rep. Biol., 15, 12 (Abstr.).

TSONIS C. G., CAHILL L. P., CARSON R. S., FINDLAY J. K., 1984 . Identification at the onset of luteolysis of follicles capable of ovulation in the ewe. J. Reprod. Fert., 70, 609-614.

TSONIS C. G., CAHILL L. P., CHAMLEY W. A., FINDLAY J. K., 1982. Which follicles are selected to ovulate in sheep. Proc. aust. Soc. rep. Biol, 14, 80 (Abstr.).

WEBB R., ENGLAND B. G. 1982. Identification of the ovulatory follicle in the ewe : associated changes in follicle size, thecal and granulosa cell luteinizing hormone receptors, antral fluid steroïds and circulating hormones during the preovulatory period. Endocrinology, 110, 873881.

WEHRENBERG W. B., DIERSCHKE D. J., WOLF R. C., MEYER R. K., 1979. The effect of ligating the ovarian and uterine arteries on ovarian function in cyclic rhesus monkeys. Biol. Reprod., 20, 596-600.

WELSCHEN R., DULLAART J., 1976. Administrations of antiserum against ovine FSH or LH at proestrus in the rat : effects on follicular development during the oncoming cycle. Endocrinology, 70, 301-306.

WOODS G. L., GINTHER O. J., 1983. Recent studies relating to the collection of multiple embryos in mares. Theriogenology, 19, 101-108.

ZELEZNIK A. J., 1981. Premature elevation of systemic estradiol reduces serum levels of FSH and lengthens the follicular phase of the menstrual cycle of rhesus monkeys. Endocrinology, 109, $352-355$.

ZELEZNIK A. J., SCHULER H. M., REICHERT L. E., 1981. Gonadotropin binding sites in the rhesus monkey ovary: role of the vasculature in the selective distribution of human chorionic gonadotropin to the preovulatory follicle. Endocrinology, 109, 356-362. 